\title{
A high incidence of species substitution and mislabelling detected in meat products sold in South Africa
}

\author{
Donna-Mareè Cawthorn ${ }^{\mathrm{a}}$, Harris A. Steinman ${ }^{\mathrm{b}}$, Louwrens C. Hoffman ${ }^{\mathrm{a}}$
}

a Department of Animal Sciences, University of Stellenbosch, Private Bag X1, Matieland 7602, South Africa b Food \& Allergy Consulting \& Testing Services (F.A.C.T.S), P.O. Box 565, Milnerton 7435, South Africa

\begin{abstract}
Due to their high market value, meat products are often targets for species substitution and adulteration. DNA-based methods are recognized as the most appropriate means to detect such fraudulent practices, however, these have not been extensively employed for the authentication of meat products available in South Africa. The aim of this study was to utilize a variety of molecular techniques to evaluate the extent of meat product mislabelling prevailing on the local market. A total of 139 processed meat products (minced meats, burger patties, deli meats, sausages and dried meats) were collected from retail outlets and butcheries in South Africa. The enzyme-linked immunosorbent assay (ELISA) was employed for the detection of undeclared plant proteins (soya and gluten) in the samples. A commercial DNA-based LCD array was used to screen the samples for the presence of 14 animal species, the results of which were confirmed by species-specific polymerase chain reaction (PCR) and in some cases also DNA sequencing. The results revealed that 95 of 139 (68\%) samples contained species which were not declared on the product labelling, with the incidence being highest in sausages, burger patties and deli meats. Soya and gluten were identified as undeclared plant proteins in a large number of samples $(>28 \%)$, while pork $(37 \%)$ and chicken $(23 \%)$ were the most commonly detected animal species. Unconventional species such as donkey, goat and water buffalo were also discovered in a number of products. Overall, this study confirmed that the mislabelling of processed meats is commonplace in South Africa and not only violates food labelling regulations, but also poses economic, religious, ethical and health impacts.
\end{abstract}

\section{Introduction}

As the world population rises, the demand for meat products continues to escalate in almost all regions of the globe, especially in developing countries (Delgado, 2003). In South Africa, total meat consumption is estimated at $41.0 \mathrm{~kg}$ per capita per year, which is the second highest in Africa (after Ghana) and closely mirrors the global meat consumption estimates of $41.2 \mathrm{~kg}$ per capita per year (FAO, 2009, pp. 9 -13; Taljaard, Jooste, \& Asfaha, 2006). Meat is, however, one of the most highlypriced food commodities in this country, which places considerable financial pressure on a population where over 50\% live below the poverty line (Hagen-Zanker, Morgan, \& Meth, 2011, pp. 1 - 6). In particular, the prices of beef from cattle and mutton from sheep have escalated significantly since the year 2000 and these are now considered as luxury items in South Africa, retailing at over double the price of chicken and up to 1.5-fold more than pork (DAFF, 2011, pp. 1 - 58; NAMC, 2010, pp. 1 25).

Aside from price, other aspects that drive the selection of meat products include quality and nutritional attributes. Modern consumers are increasingly aware of their health and are demanding more comprehensive information on the origin, composition and safety of the foods they consume (Grunert, 2002; Taljaard et al., 2006; Verbeke \& Ward, 2006). Regulatory bodies in South Africa have responded to such consumer desires by publishing new legislation to promote transparency and the proper description of food products. These include the Regulations relating to the Advertising and Labelling of Foodstuffs (R.146/2010) (DoH, 2010, pp. 3 - 53) and the Consumer Protection Act (R.467/2009) (DTI, 2009, pp. 1 - 186). The former regulations require the mandatory declaration of all food components on food labels, including certain designated common allergens, while the latter protects individuals from exploitation of any kind in the marketing and sale of consumer goods. In spite of the implementation of more stringent food labelling regulations locally and globally, the adulteration or misrepresentation of food products for illicit financial gain continues to be a common feature of society (Shears, 2010; Singh \& Neelam, 2011).

Historically, meat has not been widely associated with adulteration since this has most often been marketed as fresh, easily recognizable joints (Nakyinsige, Che Man, \& Sazili, 2012). However, with the escalating prices of commercial meat commodities, the globalization of food trade and the increased processing of meat into value-added products, the incidence of meat adulteration and fraud 
has become more commonplace (Ayaz, Ayaz, \& Erol, 2006; Flores-Munguia, Bermudez-Almada, \& Vazquez-Moreno, 2000; Vandendriessche, 2008). Typical cases of intentional meat adulteration involve the substitution or addition of animal proteins (normally cheaper varieties) or plant proteins (such as soyabean or grain derivatives) not declared as such in the ingredient list (Flores-Munguia et al., 2000). While the presence of undeclared species in meat may be unintentional in some cases, due to ignorance or cross contamination, such occurrences are generally no less negligent. Cross contamination can arise, for instance, when improperly cleaned equipment is used to process meat from more than one species (Owusu-Apenten, 2002, pp. 196 - 248).

The ability to detect less desirable or objectionable species in meat products is important not only for economic, health, religious and ethical reasons, but also to ensure fair trade and compliance with legislation (Ballin, Vogensen, \& Karlsson, 2009; Nakyinsige et al., 2012; Spink \& Moyer, 2011). Most analytical methods utilized to date for meat authentication have relied on the detection of species-specific proteins or DNA (Ballin et al., 2009; Leighton Jones, 1991; Meyer \& Candrian, 1996). Today, however, DNA is considered to be the most appropriate molecule for species detection and identification in foods (Singh \& Neelam, 2011). Unlike proteins, DNA is relatively stable at high temperatures, meaning that it can be analysed not only in fresh and frozen food products, but also in processed, degraded and mixed commodities (Lenstra, 2003). Additionally, while the presence and characteristics of proteins depend on the tissue type being analysed, DNA exists and is identical in almost all cells, and the diversity afforded by the genetic code permits the discrimination of even closely-related species (Ballin, 2010; Lockley \& Bardsley, 2000). DNA-based methods that have been applied for species identifications include DNA hybridization, polymerase chain reaction (PCR)restriction fragment length polymorphism (PCR - RFLP) analysis, species-specific PCR, multiplex PCR, real-time PCR and PCR sequencing (Chen, Liu, \& Yao, 2010; Che Man, Aida, Raha, \& Son, 2007; Dalmasso et al., 2004; Ebbehøj \& Thomsen, 1991a; 1991b; Karlsson \& Holmlund, 2007; Lopez-Andreo, Lugo, Garrido-Pertierra, Prieto, \& Puyet, 2005).

In spite of the utility of DNA in permitting explicit species identifications and the fact that meat adulteration is suspected to be occurring on the South African market (Anonymous, 2011; Schroeder, 2011; Weiner, 2011), such techniques have not been extensively employed for the authentication of meat commodities commercially available in this country. The aim of this study was to utilize a variety of molecular techniques in order to evaluate the extent of meat product mislabelling prevailing on the local market, the most commonly implicated commodities and substituted species, and the impacts that such practices hold in terms of consumer confidence and fair trade.

\section{Materials and methods}

\subsection{Samples and sample collection}

A chi-square $\left(\chi^{2}\right)$ test power analysis (StatSoft Inc., 2009) was used to assess the sample size required to evaluate the prevalence of meat species substitution or contamination on the South African market. A total of 139 packaged meat products were purchased over a five-month period (April 2012 to August 2012) from retail outlets in four provinces of South Africa, namely the Western Cape (WC, $n$ $=38)$, Eastern Cape (EC, $\mathrm{n}=28)$, KwaZulu-Natal $(\mathrm{KZN}, \mathrm{n}=38)$ and Gauteng $(\mathrm{GP}, \mathrm{n}=35)$. The aforementioned provinces were selected for the sample collection based on the fact that these are the most highly populated provinces in South Africa and contribute most substantially to the country's gross domestic profit (GDP) (StatsSA, 2012). Where possible, attempts were made to balance the sample sizes from high income and low income regions within each province, as well as the types of stores visited in each district. The retail outlets selected for sample collection included both supermarkets and butcheries and were identified for inclusion prior to the initiation of the study. For this purpose, supermarkets were defined as those stores that sold meat and various other grocery items, while butcheries were defined as those stores selling primarily meat commodities. Five different categories of processed meat products were collected for analysis, namely minced meats, burger patties, comminuted deli meats (including luncheon loaves, polonies, vienma sausages and meat spreads), raw sausages ${ }^{1}$ (including boerewors*, species sausage ${ }^{* *}$ and mixed species sausage $\dagger$ ) 
and dried meats (including biltong ${ }^{2}$ and dried sausage) (Table 1). The full ingredient list declared on the packaging of each sample was recorded and was consulted during subsequent interpretation of the results. All samples were stored at $-20^{\circ} \mathrm{C}$ following collection.

\subsection{Detection of plant-derived ingredients (soya and gluten)}

Soya and gluten (as a marker for the presence of wheat, rye or barley derivatives or flours) were selected as indicators of plant substitutes in the samples due to their extensive use in processed meats, the fact that they are both classified as 'common allergens' in South Africa and due to the propensity for these cheaper constituents to be fraudulently added to meats for financial gain (DoH, 2010, pp. 3 53; Rencová \& Tremlová, 2009). Meat samples were analysed for the presence of soya using a commercial quantitative enzyme-linked immunosorbent assay (ELISA) (Veratox $(\mathbb{B})$ Soy Allergen, product code 8410, Neogen Corporation, supplied by Analytical Diagnostic Products, Cape Town, South Africa) in accordance with the protocol described in the kit insert. The antilbodies utilised in this ELISA are capable of detecting both raw and processed soya and the kit has a range of quantification of 10.0 - $100.0 \mathrm{mg} \mathrm{kg}^{-1}$ soya. Assays were performed in duplicate on all samples. Quantification of the levels of soya in the products was computed using Veratox ${ }^{\circledR}$ Windows Software (Product code 9305W, supplied by Analytical Diagnostic Products).

\begin{tabular}{|c|c|}
\hline Product description & $n$ \\
\hline \multicolumn{2}{|l|}{ 1. Minced meats $(n=41)$} \\
\hline Beef mince & 32 \\
\hline Mutton/lamb mince & 5 \\
\hline Venison mince & 4 \\
\hline \multicolumn{2}{|l|}{ 2. Burger patties $(n=20)$} \\
\hline Beef burgers & 14 \\
\hline Mutton/lamb burgers & 3 \\
\hline Ostrich burgers & 1 \\
\hline Burgers (no species declared) & 2 \\
\hline \multicolumn{2}{|l|}{ 3. Deli meats $(n=33)$} \\
\hline Chicken vienna & 8 \\
\hline Ostrich vienna & 2 \\
\hline Beef vienna & 1 \\
\hline Vienna (mixed species) & 8 \\
\hline Pork frankfurter & 1 \\
\hline Chicken polony & 5 \\
\hline French polony & 3 \\
\hline Beef loaf & 2 \\
\hline Beef and pork loaf & 2 \\
\hline Pork liver spread & 1 \\
\hline \multicolumn{2}{|l|}{ 4. Raw sausages $(n=35)$} \\
\hline Mutton/lamb sausage & 17 \\
\hline Beef sausage & 11 \\
\hline Chicken sausage & 4 \\
\hline Pork sausage & 1 \\
\hline Ostrich sausage & 1 \\
\hline Kudu sausage & 1 \\
\hline \multicolumn{2}{|l|}{ 5. Dried meats $(n=10)$} \\
\hline Beef dried sausage & 2 \\
\hline Beef biltong & 4 \\
\hline Kudu biltong & 2 \\
\hline Springbok biltong & 1 \\
\hline Blesbok biltong & 1 \\
\hline Total (all products) & 139 \\
\hline
\end{tabular}

\footnotetext{
${ }^{1}$ Types of sausage marketed in South Africa for which specific regulations exist governing their composition (DoH, 1990). Raw boerewors* shall be manufactured from the meat of any animal of the bovine, ovine, porcine or caprine species or from a mixture of two or more thereof, shall be contained in an edible casing, and - a) shall contain a minimum of $90 \%$ total meat content and not more than $30 \%$ fat content, b) shall contain no offal except where such offal is to be used solely as the casing of the raw boerewors, c) shall contain no mechanically recovered meat, d) may contain a maximum of $0.02 \mathrm{~g}$ calcium per $100 \mathrm{~g}$ of the product mass. In or connection with the manufacture of raw boerewors, no ingredients shall be added except - a) cereal products or starch, b) vinegar, spices, herbs, salt or other harmless flavourants, c) permitted food additives, d) water. Raw species sausage** shall be manufactured predominantly from the meat of a specific animal or bird species, shall be contained in an edible casing, and: a) shall contain a minimum of $75 \%$ total meat content, of which a minimum of $75 \%$ shall be meat of the predominant species (expressed in the product description), and a maximum of $25 \%$ may be meat from any one or more species. Raw mixed species sausage + shall be manufactured from any mixture of the meat of two or more a species of animal or bird, shall be contained in an edible casing, and snall contain a minimum of $75 \%$ total meat content. Both species sausage** and mixed species sausage + : i) shall not contain more than $30 \%$ fat content, ii) shall contain no offal except where such offal is to be used solely as the casing of the product, $\mathrm{d}$ ) shall contain no mechanically recovered meat, d) may contain a maximum of $0.02 \mathrm{~g}$ calcium per $100 \mathrm{~g}$ of the product mass. In or connection with the manufacture of raw species and raw mixed species sausage, no ingredients shall be added except - a) cereal products or starch, b) vinegar, spices, herbs, salt or other harmless flavourants, c) permitted food additives, d) water. Any person that sells a foodstuff referred to as boerewors*, species sausage** or mixed species sausag $\epsilon^{*}$ shall provide a complete list of ingredients on the label.

${ }^{2}$ Lean meat that is cut into long strips, flavoured with spices and dried.
} 
The RIDASCREEN ${ }^{\circledR}$ Gliadin ELISA (r-Biopharm, Art. No. R7001, supplied by AEC Amersham, Cape Town, South Africa) was used for the detection and quantification of the levels of gluten in the meat samples following the instructions of the manufacturer. This ELISA kit has a limit of detection of $3.0 \mathrm{mg} \mathrm{kg}^{-1}$ gluten and a range of quantification of $5.0-80.0 \mathrm{mg} \mathrm{kg}^{-1}$ gluten. Gluten results were interpreted using RIDA ${ }^{\circledR S O F T}$ Win software (product code Z9999, supplied by AEC Amersham). The standards supplied in both ELISA kits were used during the performance of the assays. Negative control samples (containing no soya or gluten) and positive control samples (containing soya or gluten, respectively) were additionally included in the tests to verify the accuracy of the generated results.

\subsection{DNA extraction}

DNA was extracted from ca. $500 \mathrm{mg}$ homogenized meat samples using the SureFood ${ }^{\circledR}$ PREP Kit (product code S1012, r-Biopharm, supplied by AEC-Amersham), following the manufacturer's instructions. DNA extractswere stored at $-20^{\circ} \mathrm{C}$ until further analysis.

\subsection{Animal species screening}

The meat samples were screened for the presence of 14 animal species using a commercial qualitative LCD array kit (Meat Species 1.6, Chipron GmbH, Berlin, Germany) according to the manufacturer's instructions. The oligonucleotide primer mix supplied in the kit targets a ca. 125 base pair (bp) region of a highly conserved region of the ribosomal RNA (rRNA) gene within the mitochondrial genome (mtDNA) of animal species. The fields on the LCD chips incorporate DNA capture probes which are specific to nine meat species and five poultry species, which include: beef (Bos taurus), water buffalo (Bubalus bubalis), pork (Sus scrofa), sheep (Ovis aries), goat (Capra hircus), horse (Equus caballus), donkey (Equus asinus), rabbit (Oryctolagus cuniculus), hare (Lepus europaeus), chicken (Gallus gallus), turkey (Meleagris gallopavo), goose (Anser albifrons), mallard duck (Anas platyrhyncos) and Muscovy duck (Cairina moschata). This kit was selected with the anticipation that the aforementioned species would be the most likely animal protein substitutes in meat products available on the South African market. The spotting patterns obtained on each field of the chips were interpreted using the LCD-array slide scanner PF3650 and SlideReader Analysis Software supplied by Chipron GmbH.

\subsection{Species-specific PCR}

All positive results obtained for animal species in the meat samples using the LCD array were confirmed using species-specific PCR methods targeting short fragments of the mtDNA, as previously described in the scientific literature (Table 2). The Taq DNA polymerase (Biotaq ${ }^{\mathrm{TM}}, 5 \mathrm{U} . \mu \mathrm{l}^{-1}$ ), PCR reaction buffer (Biotaq ${ }^{\mathrm{TM}}, 10 \mathrm{x} \mathrm{NH}$ ), $\mathrm{MgCl}_{2}$ (Biotaq ${ }^{\mathrm{TM}}, 50 \mathrm{mM}$ ) and dNTPs (Bioline, $10 \mathrm{mM}$ ) used in the PCR reaction mixtures were obtained from Celtic Diagnostics (Cape Town, South Africa). Oligonucleotide primers were synthesized by Integrated DNA Technologies (IDT) (supplied by Whitehead Scientific, Cape Town, South Africa).

PCR reactions were carried out in a Labnet MultiGene ${ }^{\mathrm{TM}}$ Gradient Thermal Cycler (Woodbridge, USA). PCR products $(5 \mu \mathrm{l})$ were separated on $1.5 \%(\mathrm{~m} / \mathrm{v})$ agarose (Sigma-Aldrich, Gauteng, South Africa) gels, containing $0.02 \mu \mathrm{ml}^{-1}$ ethidium bromide, in $0.5 \mathrm{x}$ TBE electrophoresis buffer. The separated PCR fragments were visualized under an ultraviolet transilluminator and were analysed using UVIband Quantitative Software (UVItec Limited, United Kingdom).

\subsection{Sequencing and sequence analysis}

A DNA sequencing approach was employed for species authentication of biltong (dried meat) samples, since some of these were indicated to be produced from local antelope species which would not be readily identified using the LCD array. DNA obtained from the eight biltong samples was amplified using PCR primers that target a $c a .450 \mathrm{bp}$ fragment of the mtDNA cytochrome $b$ (cyt b) gene following the method described by Verma and Singh (2003). PCR amplification success was 
confirmed by gel electrophoresis and PCR products were purified with the NucleoFast 96 PCR Cleanup Kit (Macherey-Nagel, supplied by Separations, Gauteng, South Africa). The P'CR amplification products were sequenced using BigDye chemistry and analysis on an ABI 3100 Genetic Analyzer (Applied Biosystems, Foster City, USA). The generated sequences were identified in GenBank (www.ncbi.nlm.nih.gov) using the nucleotide basic local alignment search tool (BLASTn). As a general rule, a top species match with a sequence similarity of at least $98 \%$ was used to designate potential species identifications (Barbuto et al., 2010).

\begin{tabular}{|c|c|c|c|c|}
\hline $\begin{array}{l}\text { Species-specific } \\
\text { PCR }\end{array}$ & Specificity & Target gene & $\begin{array}{l}\text { Amplicon } \\
\text { size (bp) }\end{array}$ & Reference \\
\hline Beef & Bos spp. & cyt $b$ & 113 & $\begin{array}{l}\text { Gupta, Rank, } \\
\text { \& Joshi, } 2011\end{array}$ \\
\hline Water buffalo & $\begin{array}{l}\text { Bubalus } \\
\text { bubalis }\end{array}$ & cyt $b$ & 154 & Gupta et al., 2011 \\
\hline Pork & Sus scrofa & cyt $b$ & 130 & Tanabe et al., 2007 \\
\hline Sheep & Ovis aries & cyt $b$ & 275 & Herman, 2001 \\
\hline Donkey & Equus asinus & ND2 & 145 & $\begin{array}{l}\text { Kesman, Yetim, } \\
\text { \& Sahin, } 2010\end{array}$ \\
\hline Poultry & $\begin{array}{l}\text { Gallus gallus } \\
\text { Meleagris spp. }\end{array}$ & $12 \mathrm{~S}$ rRNA & 183 & $\begin{array}{l}\text { Dalmasso } \\
\text { et al., } 2004\end{array}$ \\
\hline
\end{tabular}

cyt $b$ : cytochrome $b$ gene; ND2: NADH dehydrogenase subunit $2 ; 12$ S rRNA: 12S ribosomal RNA.

\subsection{Evaluation of species authenticity and mislabelling}

For the evaluation of the accuracy of meat product labelling, the species identifications made using the LCD array and confirmed through species-specific PCR and DNA sequencing were compared with the species declared on the product packaging.

\section{Results}

Overall, the presence of horse (E. caballus), rabbit (O. cuniculus), hare (L. europaeus), goose (A. albifrons), mallard duck (A. platyrhyncos) and Muscovy duck (C. moschata) was not identified in any of the 139 samples evaluated (Fig. 1A-F). However, undeclared soya, gluten, beef (B. taurus), water buffalo (B. bubalis), pork (S. scrofa), sheep (O. aries), goat (C. hircus), donkey (E. asinus) and chicken (G. gallus) were detected in certain samples and each product category is subsequently addressed in turn.

\subsection{Minced meat products}

Undeclared soya was detected with the ELISA in five of the 41 (12\%) mince samples (Fig. 1A), with three of these testing for levels exceeding $1000 \mathrm{mg} \mathrm{kg}^{-1}$ soya (Fig. 2A). While gluten was declared in the ingredient lists of three samples marketed as 'savoury mince', undeclared gluten was detected in $5(13 \%)$ of the remaining mince samples (Fig. 1A), with levels ranging in the various products from low $\mathrm{mg} \mathrm{kg}^{-1}$ values to those exceeding the upper limit of quantification (LOQ) of the ELISA ( $>80 \mathrm{mg}$ $\mathrm{kg}^{-1}$ gluten) (Fig. 2B).

In terms of the detection of animal species, pork was the most common undeclared species found in the mince products. The presence of pork was only declared in the ingredient list of one of the 41 mince products tested. However, 15 of $40(38 \%)$ samples in which pork was not declared tested positive for this species (S. scrofa) with the DNA-based methods used (Fig. 1A). While the large majority of the mince products tested were labelled as 'beef mince' (Table 1, Fig. 1A), undeclared beef (B. taurus) was detected in two samples from KZN labelled as 'mutton mince' and in another from EC labelled as 'venison mince'. A further seven products labelled only as 'beef mince' tested positive for mutton (sheep, O. aries) in addition to beef, while three products labelled as 'beef 
mince' and three labelled as 'mutton mince' were found to contain undeclared chicken (G. gallus) (Fig. 1A). Goat, which represents a less common meat species processed for the retail sector in south Africa, was detected in one sample labelled as 'mutton mince' collected from a prominent supermarket chain in KZN. In addition, two samples marketed as 'beef mince' and expected to comprise meat from domestic cattle appeared to be completely substituted with meat from Asian water buffalo (Fig. 1A), testing negative for Bos spp. and positive for B. bubalis with both the LCD array and species-specific PCR methods.

\subsection{Burger patties}

Undeclared soya and gluten were found at high frequencies and generally at high levels in the burger patties analysed. Soya was not declared on the labels of any of the samples evaluated in this category, however, 7 (35\%) samples tested positive for soya (Fig. 1B) with most of these containing levels exceeding $1000 \mathrm{mg} \mathrm{kg}^{-1}$ (Fig. 2A). Of the 11 burger products in which gluten was not declared as an ingredient, eight of these $(73 \%)$ produced positive results for gluten, six of which tested for values which were above the LOQ of the ELISA ( $>80 \mathrm{mg} \mathrm{kg}^{-1}$ gluten) (Fig. 1B).

Chicken was the most common undeclared animal species found in the burger patties (Fig. 1B), not declared in any of the samples but detected in $8(40 \%)$ of these. Undeclared sheep and pork were detected in $35 \%$ and $30 \%$ of these samples, respectively. One burger sample marketed as 'ostrich patties' was found to contain undeclared beef, while one sample labelled as 'beef patties' tested positive for the presence of water buffalo (B. bubalis).

\subsection{Deli meats}

The incidence of undeclared species in the deli meats category was generally lower than that observed in the mince and burger categories (Fig. 1C). The most common undeclared constituents identified in this category were plant-based proteins. Of the 33 processed deli meats, soya was declared in 18 of the samples and gluten was declared in 11 . However, in those samples where the presence of these plant proteins was not declared on the labels, 7 of $15(47 \%)$ and 9 of $22(41 \%)$ tested positive for soya and gluten, respectively (Fig. 1C). The levels of soya determined in these samples were mostly high $\left(>1000 \mathrm{mg} \mathrm{kg}^{-1}\right)$ (Fig. 2A), while most samples tested for lower levels of gluten $\left(<20 \mathrm{mg} \mathrm{kg}^{-1}\right)$ (Fig. 2B).

Pork was found to be one of the more commonly used animal-derived ingredients in the deli meats, being declared in 11 of the 33 products evaluated (Fig. 1C). Nonetheless, the undeclared presence of this species appeared to be almost as frequent, with 7 (32\%) of the samples testing positive for this species where this was not stated on the label. When compared to pork, chicken and beef were more frequently declared as ingredients in the deli meats (indicated on the labels of $13 \%$ and $12 \%$ of the products, respectively), however, only two samples in this category tested positive for undeclared chicken and one tested positive for undeclared beef (Fig. 1C).

\subsection{Raw sausages}

Of all the product categories evaluated, the prevalence of undeclared plant and animal-derived species was highest in the raw sausage samples. Of 30 sausage products where soya was not indicated as a component ingredient, this plant protein was found in 14 (47\%) of the samples (Fig. 1D), eight of which contained $>1000 \mathrm{mg} \mathrm{kg}^{-1}$ soya (Fig. 2A). Undeclared gluten was detected in 13 of $16(81 \%)$ sausage samples (Fig. 1D), with levels of $20-80 \mathrm{mg} \mathrm{kg}^{-1}$ gluten determined in five samples and $>80$ $\mathrm{mg} \mathrm{kg}{ }^{-1}$ in eight samples (B).

As with the mince and deli meats, pork was the main undeclared animal species identified in the sausages. Pork was only declared in two of the 35 sausage samples analysed, however, this species was detected in $17(52 \%)$ samples for which there was no indication of its presence on the labels (Fig. 1D). Chicken was also found to be a frequent substitute or contaminant in sausages, identified as an undeclared species in $12(39 \%)$ sausage samples. Mutton (sheep) and beef were listed as ingredients 
in 16 and 12 of the sausage samples, respectively. Nonetheless, of those samples where the presence of the latter two species was not specified on the packaging, $9(47 \%)$ tested positive for sheep and 7 $(30 \%)$ tested positive for beef. Undeclared goat was detected in three sausage samples (two labelled as 'mutton sausage' and one as 'lamb boerewors'), while water buffalo was identified in a sample sold in a supermarket in EC as 'barbeque beef grillers' (Fig. 1D). One sausage sample labelled as 'quality beef sausage', collected from a KZN butchery, tested positive for beef as the name suggested. However, DNA from donkey (E. asinus) was co-detected in the aforementioned sample (Fig. 1D), a result that was confirmed using a donkey-specific PCR method (Table 2).

\subsection{Dried meats}

Soya was neither declared nor detected in any of the 10 dried meat samples analysed (Fig. 1E). While gluten was declared as an ingredient in three of these samples, a further three tested positive for this plant-derived component, although the levels detected were generally low ( $<20 \mathrm{mg} \mathrm{kg}^{-1}$ gluten). Pork was the only undeclared animal species identified in the dried meat samples with the LCD array and species-specific PCR, co-detected along with beef in a sample sold as 'beef dried sausage'.

The results obtained from the sequencing of a cyt b gene fragment indicated that 7 of $8(88 \%)$ biltong samples were correctly labelled in terms of the species indicated on the packaging (Table 3). For samples labelled as 'beef biltong', DNA sequencing revealed $100 \%$ sequence similarity between the enclosed meats and B. taurus. In addition, the sequences generated from two 'kudu biltong' samples and one 'blesbok biltong' sample showed $99 \%$ similarity with those sequences available in GenBank for Tragelaphus strepsiceros (kudu) and Damaliscus pygargus (blesbok), respectively. However, one sample denoted as 'springbok biltong' rather exhibited $99 \%$ sequence similarity with blesbok $(D$. pygargus) (Table 3 ).

\section{Discussion}

The results emerging from the studies of Hsieh,Woodward, and Ho (1995) and Ayaz et al. (2006) indicated that meat species substitution occurs more regularly in processed meat commodities, for instance in ground, comminuted, cured and value-added products. One possible reason for this may lie in the fact that deliberate substitution with cheaper species is more difficult to detect in such products by visual observation than it is in fresh, intact meat. Processing techniques often lead to changes in the appearance, colour, texture and even flavour of meat products, meaning that the origins of constituents can be easily disguised in the meat mixture (Flores-Munguia et al., 2000). A further reason for these findings could be due to the higher propensity for accidental cross contamination to occur during processing, due to improper handling and the use of shared equipment (Owusu-Apenten, 2002, pp. 196-248). Using the aforementioned rationale, processed meats representing mince, burger patties, deli meats, raw sausages and dried meats (Table 1) were selected for species authentication in this study. 

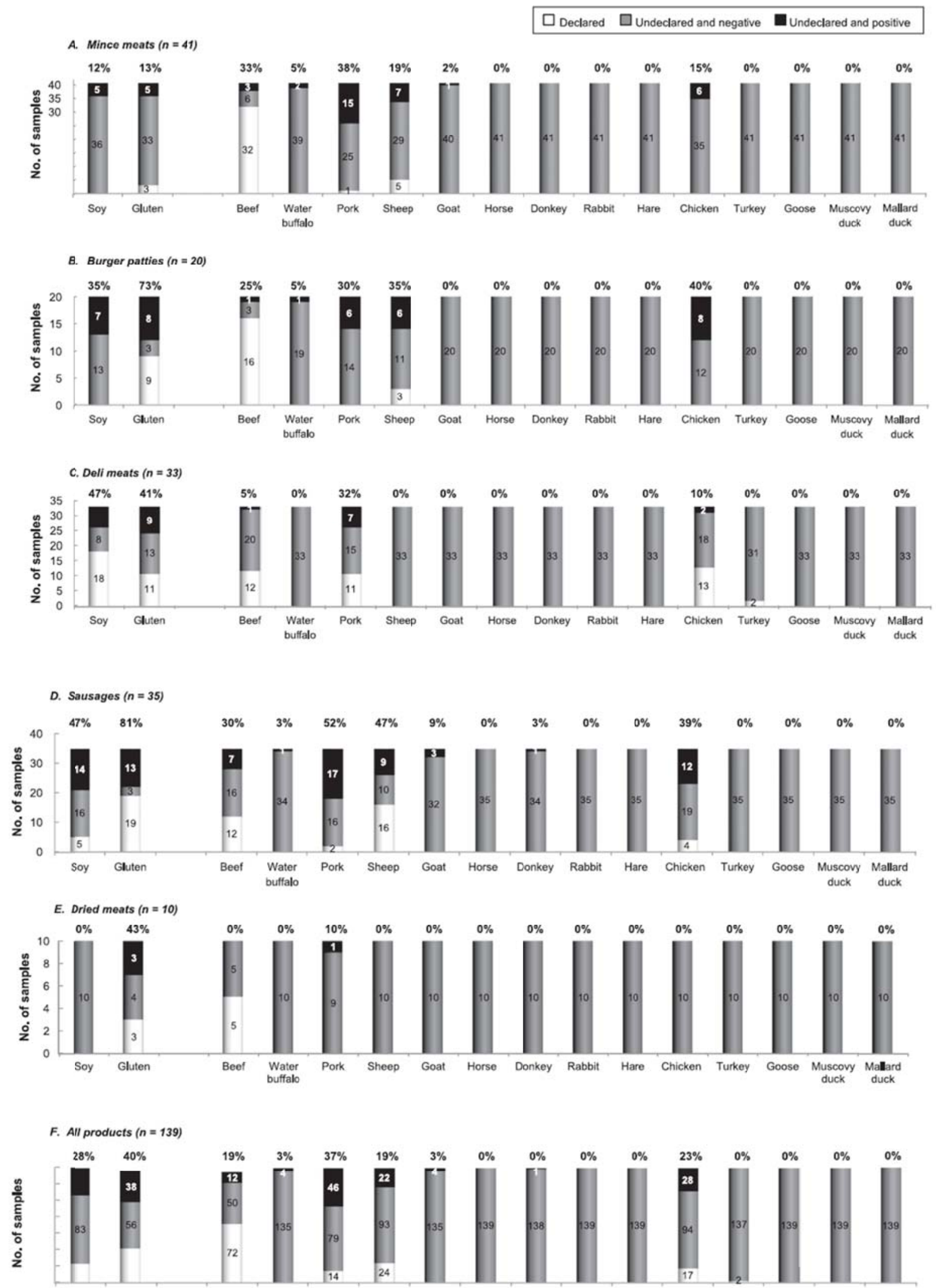

Fig. 1. Graphical representations of the extent of meat product mislabelling showing the proportion of meat samples within each product category (A-E) and overall (F) where a specific species was declared, the proportion where this was not declared and the sample tested negative for that species and the proportion where this was not declared and the sample tested positive for that species. The percentage values listed above each graph refer to the percentage of products where a species was not declared that tested positive for the respective species. 


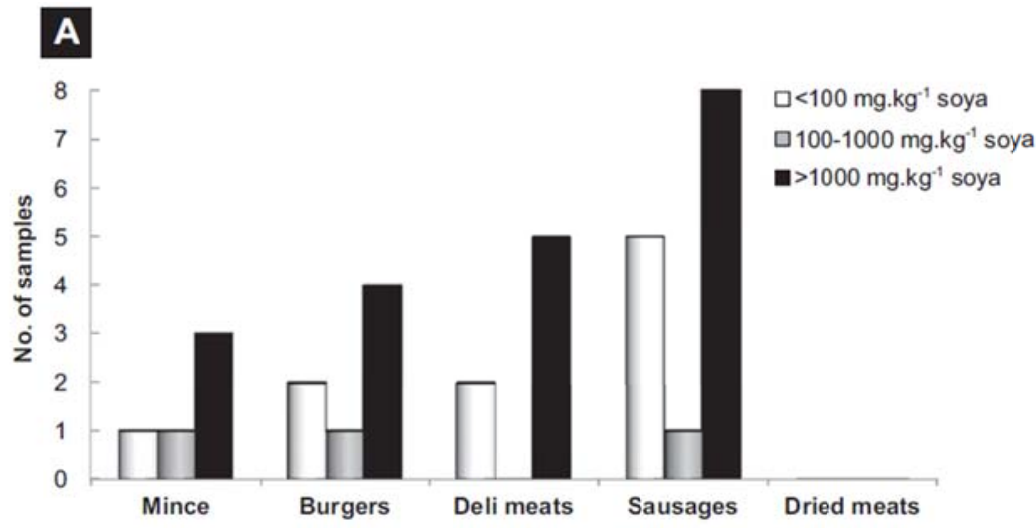

B

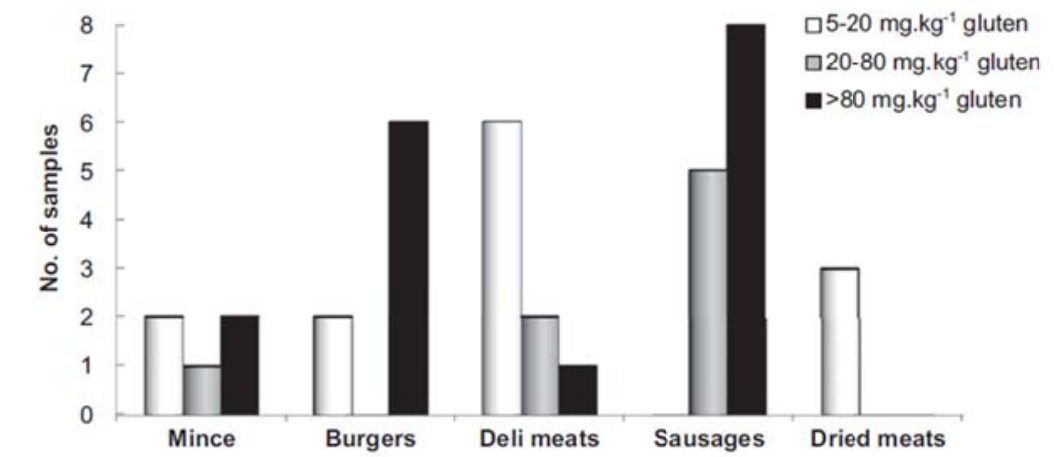

Fig. 2. The number of meat samples in each product category testing for various levels of undedared soya (A) and gluten (B)

Table 3

Identification results based on cytochrome $b$ gene sequencing for eight biltong (dried meat) samples collected in South Africa, where cases of suspected mislabelling are indicated with grey shading.

\begin{tabular}{llllcc}
\hline Product marketed as: (expected species) & $n$ & Target sequence & Species identification & Sequence similarity (\%) & GenBank accession no. \\
\hline Beef biltong (Bos spp.) & 4 & cyt $b$ gene $(450 \mathrm{bp})$ & Bos taurus (beef) & $100 \%$ & GU947021 \\
Kudu biltong (Tragelaphus strepsiceros) & 2 & cyt $b$ gene $(450 \mathrm{bp})$ & T. strepsiceros (kudu) & $99 \%$ & JN632708 \\
Blesbok biltong (Damaliscus pygargus) & 1 & cyt b gene $(450 \mathrm{bp})$ & Damalisaus pygargus (blesbok) & $99 \%$ & AF016639 \\
Springbok biltong (Antidorcas marsupialis) & 1 & cyt b gene $(450 \mathrm{bp})$ & Damalisaus pygargus (blesbok) & $99 \%$ & AF016639 \\
\hline
\end{tabular}

Taking all the analysed products into account, undeclared plant and/or animal species were detected in 95 of $139(68 \%)$ samples, meaning that only $32 \%$ of the processed meats appeared to be accurately labelled with regard to their contents. This is of concern considering that the newly implemented food labelling legislation in South Africa (DoH, 2010, pp. 3-53) requires the declaration of all product constituents on the labels of packaged food products. The former rate of meat misrepresentation is considerably higher than that reported in the study of Ayaz et al. (2006), in which a commercial ELISA kit was used to show that $22 \%$ of meat samples obtained from the Turkish market contained species that were not declared on the product labels. A reason for this discrepancy may be that the ELISA kit used by Ayaz et al. (2006) detected the presence of only six species, while the methods used in the current study targeted 14 animal species and two plant-derived components, thus increasing the possibility of discovering undeclared constituents.

The highest incidence of species substitution or contamination was found to occur in raw sausages, followed by burger patties, deli meats, minced meats and then dried meats (Fig. 1 A-E). Although sampling differed to some degree between the four provinces in terms of both the stores visited and the products collected, the highest frequency of meat product misdescription was discovered in the samples collected in EC and KZN. Approximately $90 \%$ of the samples from these two provinces were found to contain one or more undeclared species. Interestingly, of the four provinces 
investigated, EC and KZN also have the highest percentage of low income groups in South Africa (van Aardt \& Coetzee, 2009, pp. 1-56). It is thus conceivable that cheaper components could be more frequently added to meat products sold in such locations since individuals may often be less concerned about product composition and more interested in cost savings. In a recent study evaluating the extent of fish mislabelling in South Africa (Cawthorn, Steinman, \& Witthuhn, 2012), KZN was also identified as the province showing the lowest levels of compliance with regards to the correct description of commercial marine species available on the market.

Plant-derived ingredients such as soya and wheat have attracted attention as meat substitutes for decades due to their cheaper prices compared to animal-derived components and because their addition in small quantities can enhance the technological characteristics of the final products (water binding capacity, texture) (Va-nha, Hinková, Sluková, \& Kvasni-cka, 2009). While the addition of several plant constituents is acceptable in certain processed meat products in South Africa (DoH,1990, pp. 1-5; SANS, 2011, pp. 1-37), the presence of these as undeclared ingredients constitutes a form of adulteration that holds economic, health and regulatory impacts. The South African food labelling regulations (DoH, 2010, pp. 3-53) lists soya and gluten-containing cereals (including wheat, rye, barley and their derivatives, referred to as 'significant cereals') as 'common allergens', since these are among the eight foods that cause $90 \%$ of potentially fatal food allergic reactions (Kurowski \& Boxer, 2008). These regulations, which came into effect on 1 March 2012, require the mandatory declaration of soya and gluten on labels when these are present in food products manufactured after the aforementioned date. In spite of these stipulations, positive results were obtained for undeclared soya and gluten in $33(28 \%)$ and $38(40 \%)$ of all the meat samples, respectively (all of which were produced and collected after 1 March 2012). The prevalence of these undeclared plant proteins was most pronounced in sausages, burger patties and processed meats (Fig. 1). Similar results were reported by Ren-cová and Tremlová (2009), who detected soya in 10 of 12 (72\%) processed meat products from the Czech Republic which carried no declaration of plant protein or soya. Given the frequent use of shared equipment in many food processing plants, the possibility exists for low levels of soya and gluten to unintentionally become present in meat products due to cross contamination. However, the high levels detected in most meat products (Fig. 2) raise the possibility of intentional addition of these plant sources for financial gain and not only contravene labelling regulations, but also pose a considerable risk to allergic or intolerant individuals.

Overall, pork was the most common undeclared animal species detected in the meat products, identified in 46 (37\%) samples that did not include any indication of this species on the labels (Fig. 1F). Such findings are of great concern, not only economically, but also from a religious viewpoint. For instance, restrictions on the consumption of pork exist in Muslim dietary laws (Halaal) and Jewish dietary laws (Kashrut) (Schröder, 2003, pp. 41-47) and individuals following these religions rely on accurate labelling to select products that will not compromise their beliefs.

The frequency of detection of undeclared pork was highest in sausage samples (52\%), followed by mince $(38 \%)$, deli meats (32\%), burger patties $(30 \%)$ and then dried meats $(10 \%)$. While the possibility of cross contamination with pork cannot be excluded in these cases, there appears to be an increasing tendency for food manufacturers to mix readily available pork flesh or derivatives into meat products to accrue greater profits (Aida, Che Man, Raha, \& Son, 2007; Aida, Che Man, Wong, Raha, \& Son, 2005). Animal fats from one species are also reported to be frequently substituted with those from other species (Ballin, 2010). It is thus conceivable that cheaper pork meat or fat could have been illicitly incorporated into the aforementioned products, or in the case of sausages and the dried sausage sample, pork casings may have been used to contain the products, without indication on the label. Another potential source of undeclared pork in the samples evaluated could be through the use of mechanically recovered meat (MRM), which is currently most often produced from pork and chicken carcasses (Surowiec, Fraser, Patel, Halket, \& Bramley, 2010). This paste-like substance, typically obtained by forcing carcass remains through sieves under high pressure to separate edible meat from bones, can be included as a cheap protein source in comminuted meat products such as sausages, burgers or deli meats (Surowiec et al., 2010). Nonetheless, the use of MRM is prohibited in boerewors, species sausage and mixed species sausage in South Africa (DoH, 1990, pp. 1-5) and 
when used in other processed meats, its presence and species origin must be declared in the ingredient list (SANS, 2011, pp. 1-37).

Chicken was the second most frequently detected undeclared animal species in all of the products combined (Fig. 1F). Although indicated as an intentional ingredient in 17 meat samples, a total of $28(23 \%)$ products tested positive for chicken DNA where this was not declared, the highest prevalence of which was for burger patties, sausages and mince consecutively (Fig. 1A-E). Apart from the potential for cross contamination, an explanation for the high incidence of this undeclared species in the aforementioned products could have been due to the substitution of cheaper chicken flesh or fat for more expensive beef or mutton constituents, or alternatively due to the unacknowledged incorporation of chicken MRM (Hsieh, Johnson, Wetzstein, \& Green,1996). Similar reports on the detection of undeclared poultry in ground meat products from Alabama and Turkish markets have been documented in the literature (Ayaz et al., 2006; Hsieh, Wetzstein, \& Green, 1996). Surprisingly, since chicken was found to be widely used as an ingredient in deli meats and because species substitution could be easily masked in such highly comminuted products, only two samples within this category tested positive for undeclared chicken (Fig. 1C). Thus, if cross contamination was the reason for the presence of undeclared species in deli meats, it would be expected that the latter number would be higher given the extensive inclusion of chicken in such products. In contrast to these findings, Ayaz et al. (2006) found that poultry was the major undeclared species in deli meats collected from Turkey, where 5 of 13 (38\%) cooked beef salami samples and 3 of $11(27 \%)$ beef frankfurters tested positive for the presence of poultry. In addition, these authors reported on the complete substitution of poultry meat for beef in 11 of $24(46 \%)$ fermented sausage products. Although beef was an intentional component of a large number of the meats analysed, indicated as an ingredient in 72 of $139(52 \%)$ samples, this species was detected in $12(19 \%)$ of the products where its presence was not indicated on the packaging (Fig. 1F). In addition, $22(19 \%)$ of the products for which mutton/lamb was not declared as an ingredient were found to test positive for sheep DNA (Fig. 1F). Undeclared beef was mostly found in raw sausages (Fig. 1D), however, the unspecified presence of mutton (sheep) was prominent in a number of sample categories, including sausages, minced meats and burgers. Such findings are comparable to the reports from other studies (Hsieh et al., 1995; Hsieh, Wetzstein, et al., 1996), in which beef and sheep were identified in turkey mince, pork mince and pork sausages. While the deliberate substitution of animal proteins with expensive beef or mutton is generally not anticipated, possible reasons for their undisclosed presence are due to cross contamination or the addition of nonconforming meat products/rework into non-identical formulations (Ayaz et al., 2006). An additional and probable reason for such occurrences could be attributed to actions of 'converting waste to profit', whereby unmarketable, lower-valued beef or sheep trimmings are incorporated into processed meat mixtures for the purposes of increasing their bulk (Hsieh et al., 1995). Regardless of the reasons for their existence in meat products, substitution with beef or mutton and/or the sale of mixed meats as pure meats would be considered unacceptable for certain portions of the population. For instance, the consumption of beef from cattle is taboo according to Hindu dietary laws due to the reverence shown to the cow (Schröder, 2003, pp. 41-47). Furthermore, individuals with ethical aversions to consuming meat from large livestock and those suffering from meat protein allergies need to be certain that the foods they purchase contain exactly what is indicated on the labels, and nothing else (Hargin, 1996). Furthermore, individuals with ethical aversions to consuming meat from large livestock and those suffering from meat protein allergies need to be certain that the foods they purchase contain exactly what is indicated on the labels, and nothing else (Hargin, 1996). Beef biltong and dried sausage have long been considered delicacies in South Africa, however, the popularity of dried meats produced from game species has recently increased due to consumer desires for leaner foods with more exotic qualities (Hoffman, Muller, Schutte, \& Crafford, 2004; Hoffman \& Wiklund, 2006). Due to the high commercial value of game meats and derived products, such products are increasingly becoming targets for adulteration (Mafra, Ferreira, \& Oliveira, 2008). While seven of the eight biltong samples analysed in this study were found to be correctly described with regards to species, one case of seemingly deliberate substitution involved a sample purchased as 'springbok biltong' that was subsequently identified by DNA sequencing as blesbok (Table 3). A potential reason for mislabelling blesbok as 'springbok' could be to increase the consumer appeal or marketability of the product, since springbok flavour is preferred, it is more well-known and more widely consumed by locals and tourists compared to blesbok (Hoffman, Muller, Schutte, 
Calitz, \& Crafford, 2005; Von la Chevallerie, 1972).

While water buffalo (B. bubalis) are found and consumed widely in parts of Asia (Kandapeen, Biswas, \& Rajkumar, 2009), the use of this species in the South African meat supply chain is not considered common. Water buffalo meat is similar to beef from cattle in terms of its physicochemical, nutritional and flavour profiles (Kandapeen et al., 2009), thus making it difficult to distinguish from the latter based on sensory attributes. The presence of water buffalo was discovered in a number of meat products analysed in this study (Fig. 1F), with cases including apparent substitution of this species for beef in mince (Fig. 1A) and its addition to burger patties and sausages (Fig. 1B, D). The aforementioned findings present an interesting example of how shortcomings or lack of clarity in local regulations can easily be capitalised on by some food producers for financial gain. The regulations governing meat classification and marking in South Africa (DoA, 2006, pp. 3-20) do not include definitions for use of the words 'beef' or 'bovine', although the term 'bovine' is extensively referred to within this legislation. Since water buffalo and cattle both belong to the family Bovidae and subfamily Bovinae, this could be used as rationale to substitute these two species if the former could be brought into the country for a cheaper price. In recognition of this legislative ambiguity, a revised draft of these regulations is currently being formulated in which 'bovine' is defined and the labelling of water buffalo as beef is specifically prohibited (Erasmus, 2011; DAFF, South Africa, personal communication).

Goat meat is widely consumed within rural communities in South Africa and is predominantly sold on the informal market. This species comprises a very small percentage of the commercial livestock sector and its availability in supermarkets and butcheries is very limited in comparison to other domestic meat species (beef, sheep, pig, poultry) (DAFF, 2010, pp. 6-16). The detection of goat in one 'mutton mince' and two 'mutton sausage' samples collected from supermarkets (Fig. 1) was thus not anticipated and such findings can likely be attributed to intentional addition of this species, rather than cross contamination.

Perhaps of greatest concern from a regulatory, health and ethical standpoint was the detection of undeclared donkey (E. asinus) in one meat sample (Fig.1D) sold in KZN as 'quality sausage', for which the only animal species declared was beef. Since donkey is not a species commercially processed for human consumption in South Africa, there is a high probability that this indicates a further case of intentional substitution for economic gain. Furthermore, there is uncertainty as to whether the animal in question was slaughtered, inspected and processed in a registered abattoir, given that this is not considered a conventional species in the domestic meat supply chain. The possibility thus exists that the meat may have been processed under non-sanitary conditions, which could pose potential risks to human health.

\section{Conclusions}

Consumers have the right to expect that the information provided on meat products is correct, particularly at a time when they are increasingly expressing the desire to make food choices that are consistent with their lifestyles and well-being. No studies have been published to date assessing the quality of food labelling and regulatory compliance in South Africa since the new packaged food labelling legislation (DoH, 2010, pp. 3-53) came into effect in March 2012. Specially, the current work represents the first comprehensive account of the utilisation of molecular techniques to evaluate the incidence of meat species misrepresentation and adulteration on the domestic market. In spite of the growing demands for transparency in the food industry, the results emerging from this study have revealed that the mislabelling of processed meats is a reality in South Africa and that local consumers are undoubtedly encountering undeclared animal and plant species in such commodities on a regular basis. The potential for undeclared species to become present in meat products due to accidental cross contamination and deliberate substitution has been demonstrated, the results of which hold considerable financial, religious, ethical and public health ramifications. In addition, such practices are frequently contravening legislation in South Africa and are undermining fair trade on the domestic meat market. 
Overall, such findings raise significant concern on the functioning of the meat supply chain in South Africa. While local regulations are in place to protect consumers from being sold falsely described or inferior foodstuffs, without appropriate and continuous enforcement of these, it cannot be generally accepted that correctly labelled meat products will remain available on the market. These results should thus compel government authorities to identify targets for improving meat labelling practices, to address the adequacy of authentication monitoring methods and to contemplate whether the penalties issued for non-compliance are sufficient to deter fraudulent practices. Since authorities cannot inspect or test every meat product available on the market, the entire meat industry will ultimately need to take more responsibility in complying with the relevant regulations, realizing that their failure to provide vital information on products may not only decrease consumer confidence in their organisations, but also in the meat industry as a whole.

Against this backdrop, immunological and DNA-based methods have been shown to be powerful and highly applicable tools for species identification in processed meat products, the use of which by industry and regulators could provide superior levels of precision to authentication monitoring and law enforcement. If transparency can be enhanced on the local market through industry and regulator co-operation, then public confidence in the meat supply chain will almost certainly be promoted and the demand for processed meats may be maintained or even increased. 


\section{References}

van Aardt, C. J., \& Coetzee, M. C. (2009). Personal income by province, population group, sex and income group. South Africa: Bureau of Market Research. Aida, A. A., Che Man, Y. B., Raha, A. R., \& Son, R. (2007). Detection of pig derivatives in food products for halal authentication by polymerase chain reaction-restriction fragment length polymorphism. Journal of the Science of Food and Agriculture, 87, 569-572.

Aida, A. A., Che Man, Y. B., Wong, C. M. V. L., Raha, A. R., \& Son, R. (2005). Analysis of raw meats and fats of pigs using polymerase chain reaction for halal authentication. Meat Science, 69, 47-52.

Anonymous. (November 16, 2011). South African Muslims furious at 'halal pork' scandal. BBC News Africa. http://www.bbc.co.uk/news/worldafrica-15753835 Accessed 14.12.12.

Ayaz, Y., Ayaz, N. D., \& Erol, I. (2006). Detection of species in meat and meat products using enzyme-linked immunosorbent assay. Journal of Muscle Foods,17, 214-220. Ballin, N. Z. (2010). Authentication of meat and meat products. Meat Science, 86, 577-587.

Ballin, N. Z., Vogensen, F. K., \& Karlsson, A. H. (2009). Species determination - can we detect and quantify meat adulteration? Meat Science, 83, 165-174.

Barbuto, M., Galimberti, A., Ferri, E., Labra, M., Malandra, R., Galli, P., et al. (2010). DNA barcoding reveals fraudulent substitutions in shark seafood products: the Italian case of "palombo" (Mustelus spp.). Food Research International, 43, 376-381.

Cawthorn, D. M., Steinman, H. A., \& Witthuhn, R. C. (2012). DNA barcoding reveals a high incidence of fish species misrepresentation and substitution on the South African market. Food Research International, 46, 30-40.

Che Man, Y. B., Aida, A. A., Raha, A. R., \& Son, R. (2007). Identification of pork derivatives in food products by species-specific polymerase chain reaction (PCR) for halal verification. Food Control, 18, 885-889.

Chen, S. Y., Liu, Y. P., \& Yao, Y. G. (2010). Species authentication of commercial beef jerky based on PCR-RFLP analysis of the mitochondrial $12 \mathrm{~S}$ rRNA gene. Journal of Genetics and Genomics, 37, 763-769.

DAFF (Department of Agriculture, Forestry and Fisheries). (2010). A profile of the South African goat market value chain. South Africa: DAFF.

DAFF (Department of Agriculture, Forestry and Fisheries). (2011). A profile of the South African beef market value chain. South Africa: DAFF.

Dalmasso, A., Fontanella, E., Piatti, P., Civera, T., Rosati, S., \& Bottero, M. (2004). A multiplex PCR assay for the identification of animal species in feedstuffs. Molecular and Cellular Probes, 18, 81-87.

Delgado, C. L. (2003). Rising consumption of meat and milk in developing countries has created a new food revolution. Journal of Nutrition, 133, 3907S-3910S. DoA (Department of Agriculture). (2006). Agricultural Product Standards Act, 1990 (Act 119 of 1990), regulations regarding the classification and marking of meat intended for sale in the Republic of South Africa (R. 863/2006). South Africa: Government Printing Offices.

DoH (Department of Health). (1990). Foodstuffs, Cosmetics and Disinfectants Act, 1972 (Act 54 of 1972), regulations governing the composition and labelling of raw boerewors, raw species sausage and raw mixed-species sausage (R. 2718/1990). South Africa: Government Printing Offices.

DoH (Department of Health). (2010). Foodstuffs, Cosmetics and Disinfectants Act, 1972 (Act 54 of 1972), regulations relating to the labelling and advertising of foodstuffs (R. 146/2010). South Africa: Government Printing Offices.

DTI (Department of Trade and Industry). (2009). Consumer Protection Act (Act no. 68 of 2008) (R. 467/2009). South Africa: Government Printing Offices.

Ebbehøj, K. F., \& Thomsen, P. D. (1991a). Species differentiation of heated meat products by DNA hybridization. Meat Science, 30, 221-234.

Ebbehøj, K. F., \& Thomsen, P. D. (1991b). Differentiation of closely related species by DNA hybridization. Meat Science, 30, 359-366.

Erasmus, N. (2011). Department of Agriculture, Forestry and Fisheries (DAFF), South Africa. Personal Communication.

FAO (Food and Agriculture Organization of the United Nations). (2009). The state of food and agriculture. Rome: FAO.

Flores-Munguia, M. E., Bermudez-Almada, M. C., \& Vazquez-Moreno, L. (2000). Detection of adulteration in processed traditional meat products. Journal of Muscle Foods, 11, 319-332.

Grunert, K. G. (2002). Current issues in the understanding of consumer food choice. Trends in Food Science \& Technology, 13, 275-285

Gupta, R., Rank, D. N., \& Joshi, C. G. (2011). Duplex-PCR for identification and differentiation of cattle and buffalo processed meat. Journal of Advanced Veterinary Research, 1, 13-16.

Hagen-Zanker, J., Morgan, J., \& Meth, C. (2011). South Africa's social security system: Expanding coverage of grants and limiting increases in inequality. London:

Overseas Development Institute.

Hargin, K. D. (1996). Authenticity issues in meat and meat products. Meat Science, 43, 5277-5289.

Herman, L. (2001). Determination of the animal origin of raw food by species specific PCR. Journal of Dairy Research, 68, 429-436.

Hoffman, L. C., Muller, M., Schutte, D.W., Calitz, F. J., \& Crafford, K. (2005). Consumer expectations, perceptions and purchasing of South African game meat. South African Journal of Wildlife Research, 35, 33-42.

Hoffman, L. C., Muller, M., Schutte, D. W., \& Crafford, K. (2004). The retail of South African game meat: current trade and marketing trends. South African Journal of Wildlife Research, 34, 123-134.

Hoffman, L. C., \& Wiklund, E. (2006). Game and venison meat for the modern consumer. Meat Science, 74, 197-208.

Hsieh, Y. H. P., Johnson, M. A., Wetzstein, C. J., \& Green, N. R. (1996). Detection of species adulteration in pork products using agar gel immune diffusion and enzyme linked immune sorbent assay. Journal of Food Quality, 19, 1-9.

Hsieh, Y. H. P., Wetzstein, C. J., \& Green, N. R. (1996). Retail pork products often contain meats other than pork. Highlights of Agricultural Research, 43, 22-24.

Hsieh,Y. H.P.,Woodward,B.B.,\&Ho, S. H. (1995). Detection of species substitution in raw and cooked meats using immunoassays. Journal of Food Protection, 58, 555-559.

Kandapeen, G., Biswas, S., \& Rajkumar, R. S. (2009). Buffalo as a potential food animal. International Journal of Livestock Production, 1, 001-005.

Karlsson, A. O., \& Holmlund, G. (2007). Identification of mammal species using species-specific DNA pyro sequencing. Forensic Science International, 173, 16-20.

Kesman, Z., Yetim, H., \& Sahin, F. (2010). Identification of different meat species used in sucuk production by PCR assay. GIDA, $35,81-87$.

Kurowski, J., \& Boxer, R. W. (2008). Food allergies: detection and management. American Family Physician, 77, 1687-1688.

Leighton Jones, J. (1991). DNA probes: applications in the food industry. Trends in Food Science \& Technology, 2, $28-32$.

Lenstra, J. A. (2003). DNA methods for identifying plant and animal species in food. In M. Lees (Ed.), Food authenticity and traceability (pp. 34-36). Florida: CRC Press

Lockley, A. K., \& Bardsley, R. G. (2000). DNA-based methods for food authentication. Trends in Food Science \& Technology, 11, 67-77.

Lopez-Andreo, M., Lugo, L., Garrido-Pertierra, A., Prieto, M. I., \& Puyet, A. (2005). Identification and quantitation of species in complex DNA mixtures

by real-time polymerase chain reaction. Analytical Biochemistry, 339, 73-82.

Mafra, I., Ferreira, I. M. P. L. V. O., \& Oliveira, M. B. P. P. (2008). Food authentication by PCR-based methods. European Food Research and Technology, $227,649-665$. Meyer, R., \& Candrian, U. (1996). PCR-based DNA analysis for the identification and characterization of food components. Lebensmittel-Wissenschaft und Technologie, $29,1-9$

Nakyinsige, K., Che Man, Y. B., \& Sazili, A. Q. (2012). Halal authenticity issues in meat and meat products. Meat Science, 91, 207-214

NAMC (National Agricultural Marketing Council). (2010). Media release: Food price monitor May 2010. South Africa: NAMC.

Owusu-Apenten, R. K. (2002). Food protein analysis: Quantitative effects of processing. New York: Marcel Dekker

Ren-cová, E., \& Tremlová, B. (2009). ELISA for detection of soya proteins in meat products. Acta Veterinaria BRNO, 78, 667-671.

SANS (South African National Standards). (2011). Processed meat products SANS 885 (3rd ed.). South Africa: SABS Standards Division, 1-37.

Schröder, M. J. A. (2003). Food quality and consumer value: Delivering food that satisfies. Berlin: Springer.

Schroeder, F. (November 10, 2011). Pork sold as halaal meat. Cape Argus. http://www.iol.co.za/capeargus/pork-sold-as-halaal-meat-1.1175676\#.UQkzcSeyMs4 Accessed 16.12.12.

Shears, P. (2010). Food fraud - a current issue but an old problem. British Food Journal, 112, 198e213.

Singh, V. P., \& Neelam, S. (2011). Meat species specifications to ensure the quality of meat: a review. International Journal of Meat Science, 1, 15-26.

Spink, J., \& Moyer, D. C. (2011). Defining the public health threat of food fraud. Journal of Food Science, 76, 157-163.

StatSoft, Inc. (2009). Statistica (Data analysis software system), version 9.0. Accessed 20.06.12. www.statsoft.com.

StatsSA (Statistics South Africa). (2012). Statistical release P0302: Mid-year population estimates 2011. accessed 25.08.12. http://www.statssa.gov.za.

Surowiec, I., Fraser, P. D., Patel, R., Halket, J., \& Bramley, P. M. (2010). Metabolomic approach for the detection of mechanically recovered meat in food products. Food Chemistry, 125, 1468-1475.

Taljaard, P. R., Jooste, A., \& Asfaha, T. A. (2006). Towards a broader understanding of South African consumer spending on meat. Agrekon, 45, 214-224. Tanabe, S., Miyauchi, E., Muneshige, A., Mio, K., Sato, C., \& Sato, M. (2007). PCR method of detecting pork in foods for verifying allergen labeling and for identifying hidden pork ingredients in processed foods. Bioscience Biotechnology and Biochemistry, 71, 1663-1667.

Vandendriessche, F. (2008). Meat products in the past, today and in the future. Meat Science, 78, 104-113.

Va-nha, J., Hinková, A., Sluková, M., \& Kvasni-cka, F. (2009). Detection of plant raw materials in meat products by HPLC. Czech Journal of Food Sciences, $27,234-239$.

Va-nha, J., Hinková, A., Sluková, M., \& Kvasni-cka, F. (2009). Detection of plant raw materials in meat products by HPLC. Czech Journal of Food Sciences, 27, 234-23
Verbeke, W., \& Ward, R. D. (2006). Consumer interest in information cues denoting quality, traceability and origin: an application of ordered probit models to beef labels. Food Quality and Preference, 17, 453-467.

Verma, S. K., \& Singh, L. (2003). Novel universal primers establish identity of an enormous number of animal species for forensic application. Molecular Ecology Notes, 3, 28-31.

Von la Chevallerie, M. (1972). Meat quality of seven wild ungulate species. South African Journal of Animal Science, 2, 101-103.

Wiener, M. (November 10, 2011). Questionable meat products in the spotlight. Eye Witness News. http://ewn.co.za/2011/11/10/Questionable-meat-products-inthe-

spotlight Accessed 10.12.12. 